DOI: $10.1515 /$ ausp-2015-0012

\title{
Problems Related to the Translation of Political Texts
}

\author{
Krisztina SÁROSI-MÁRDIROSZ \\ Department of Applied Linguistics \\ Sapientia Hungarian University of Transylvania (Târgu Mureş, Romania) \\ salusnostra_2000@yahoo.com
}

\begin{abstract}
This study deals with the problems related to the translation of political texts in the theoretical framework elaborated by the researchers working in the field of translation studies and reflects on the terminological peculiarities of the special language used for this text type. Consideration of the theoretical framework is followed by the analysis of a specific text spoken then written in English and translated into Hungarian and Romanian. The conclusions are intended to highlight the fact that there are no recipes for translating a political speech, because translation is not only a technical process that uses translation procedures and applies transfer operations, but also a matter of understanding cultural, historical and political situations and their significance.
\end{abstract}

Keywords: translation strategies, political language, political speech, adaptation, explicitation

\section{Introduction}

This study deals with the problems related to the translation of political speeches. The first part of the study examines some issues related to the theory of translation and presents the relationship between the source text and target text, sketching some ideas regarding equivalence in translation. The first part consists of three main subchapters: 1 . The definition of translation. 2. The relationship between the source text and the target text. 3. Equivalence in translation.

The second part of the study deals with the characterization of political language, it presents the relationship between language and politics and it highlights some of the most relevant problems associated with translating political texts. This part consists of four subchapters: 1. Language and politics. 2 . Translating political texts. 3. Adapting political texts. 4. The problematic nature of translating political speeches. 
The third part of the study highlights some practical issues related to the translation of political speeches such as the exact rendering of the message without losing the spirit of the speech itself. The chosen method was that of analyzing a parallel corpus which consists of Sir Winston Churchill's speech entitled "The Sinews of Peace" and its Hungarian and Romanian translations; we analyzed the way equivalence is created in the case of the non-translatable meanings in the two translations.

\section{Theoretical framework}

\subsection{The definition of translation}

During the past quarter-century scholars have devoted a great deal of thinking, if not research, to the translation process as such. For the most part, these have been scholars of another ilk, primary linguists, aided now and then by mathematicians and psychologists. In spite of the fact that the results of their thinking proved to be simplistic when applied to highly complex entities, we should not forget the contribution of such scientists as Trubetskoy, Havranek, Mukarovsky, Levý, Proházka, Sapir, Whorf, Loundsbury, Voegelin, Harry Hoijer, Greenberg and Weinreich to the development of Translation Studies.

Research in this field with several centuries' tradition shows that translation is neither just an act or an instance of translating nor just a product but a complex activity during which the translator transmits cultural and ideological messages as well. The enlarged perspectives and the application of the results of other domains help researchers to prove that translation is not just the expression in the target language of what has been expressed in the source language (preserving semantic and stylistic equivalences), but a more creative activity that enriches the source text with new ideological and cultural features.

To shift from one language to another is, by definition, to alter the forms. Further, the contrasting forms convey meanings which cannot but fail to coincide completely; there is no absolute correspondence between the lexicons of two different languages. Something is always "lost" or - why not - gained in the process of translation, and still the translator has to reproduce somehow the sense of the original. That's why (s)he needs to have a translation strategy built up of different translation techniques. The application of these translation techniques is more difficult in the case of the translation of political speeches, as this is often considered an activity subject to numerous strict norms (some of them having rhetoric character), or as an extremely complex form of translation (sometimes even moving towards adaptation). Thus if a researcher wants to analyze these translated texts, he will have to face many problems: what is the relation between the source 
text and the target text? what are the differences between them? and how these texts will fulfill their communicative and informative role among the target readers (i.e. whether they have the same impact without having the same context).

Translation is an incredibly broad notion which can be understood in many different ways. For example, one may talk of translation as a process or a product, and identify such sub-types as literary translation, technical translation, subtitling and machine translation. According to Lederer, "translation is a process which attempts to establish equivalence between two texts expressed in two different languages. These equivalents are, by definition, always dependent on the nature of the two texts, on their objective, on the relationship between the two cultures involved [....]." (2003: 3)

Translation can be defined as a process and as a product. Those researchers who consider that translation is just the result of a process (a text) argue that translation is nothing more than a product determined by cultural and historical needs. Product-oriented researchers consider that the area of research should be the description of individual translations. Process-oriented researchers are concerned with the process or the act of translation itself. Admittedly, the process is an unusually complex one, during which the translator creates a new text. In spite of the fact that process-oriented researchers are interested in the process of translating, the concept of "text" is an important item of their definition as well. This is obvious given that the end-product of the analyzed process is the text itself.

\subsection{The relationship between the source text and the target text}

Dealing with translation as a product or a text makes it necessary to analyze the relationship between the source text and the target text. All cognitive experience and its classification are conveyable in any existing language. No lack of grammatical device in the target language makes impossible a literal translation of the entire conceptual information contained in the original. If some grammatical category is absent in a given language, its meaning may be translated into this language by lexical means. Jakobson goes on to claim that only poetry, by definition, is untranslatable since in verse the form of words contributes to the construction of the meaning of the text. Such statements express a classical dichotomy in translation between sense/content, on the one hand, and form/style, on the other. The sense may be translated, while the form often cannot (Jakobson 1966: 238). The split between form and content is linked in many ways to the major polar split which has marked the history of Western translation theory for two thousand years, between two ways of translating: literal and free. The translator is torn between form and content (Nida 1964: 2). This is defined as the dilemma of word and spirit. Translation is art and craft in the same time. 
If all languages differ in form (and this is the essence of their being different languages), then quite naturally the forms must be altered if one wants to preserve the content. The aim of the translator is to inform the target readers by means of form. Sometimes the translator wants to influence the readers: he wants the audience to consider the translated text comprehensible and not just intelligible. The translator must pay attention to avoid ambiguity. These issues make necessary the introduction in translation studies of a new concept, that of equivalence (Nida 1964: 158).

\subsection{Equivalence in translation}

Equivalence in translation has become one of the main areas of research for scientists. Almost all researchers deal in one way or another with the nature of equivalence. According to Kinga Klaudy, researchers can be divided in two groups if we regard their opinions about equivalence: the first group argues that equivalence is a basic condition for any translation, while the second group considers that texts in different languages can be equivalent in different degrees (fully or partially equivalent), in respect of different levels of presentation (equivalents in respect of context, of semantics, of grammar, of lexis, etc.) and at different ranks (word-for-word, phrasefor-phrase, sentence-for-sentence). This latter group can be divided into two further groups: the first one is called the normative group as it tries to prescribe for the translator how to reach equivalence, the second is called the descriptive group as it tries to describe how translators obtain equivalence during translation (2003).

There is another concept, that of Katharina Reiss, who considers that equivalence depends on the type of text (1995). Nida considers that translating consists of reproducing in the receptor language the closest natural equivalent of the sourcelanguage message, first in terms of meaning and secondly, in terms of style. The closest natural equivalent is created through dynamic equivalence. Through dynamic equivalence, we can thus cater for a rich variety of contextual values and effects, which utterances carry within texts and which a literal translation would simply compromise. The opposite of dynamic equivalence is formal equivalence: a procedure purposefully selected in order to preserve a certain linguistic/rhetorical effect. These two opposing forms of equivalence can be found when analyzing political translations (Nida 1964). Some documents, such as a contract or a land register, are highly formalized and the translator must transfer all the features of the original into the translation, thus he tries to achieve both formal and dynamic equivalence at the same time. In my opinion, communicative equivalence - a term introduced by Kinga Klaudy - is the best possible form of equivalence that can be attained by a translator dealing with political texts and political speeches. This means that the translated text will have the same role amongst the target audience as the original had amongst the source audience. In the case of documents related 
to political events the equivalence of the translated text to the original depends on the type of text as these translations meet the requirements to serve as politically valid instruments in a target country (Klaudy 2003).

Never before in the history of the world have there been so many people engaged in the translation of both literal and technical materials (Klaudy 2003). Translators translate almost everything: contracts, ID cards, birth certificates, land registers, poems and novels, medical texts, technical papers, descriptions, etc. Translators are not necessarily people with linguistic interests. In some cases the translator fails to find the perfect term or fails to use the correct translation technique while rendering the information of the source text. That's why the specialized translations fail sometimes in fulfilling their communicative role. Even if they don't fail totally, these translations will be different from the rest of the translated texts. In order to analyze them, the researcher must become acquainted with the characteristics of the text-type to which the translation belongs.

\section{Political language and translation}

This part deals with the relationship between language and politics, translation and adaptation. It will present the difficulties of translating political texts and finally, it will discuss in detail one segment of this category of translation: the translation of political speeches. It will mainly underline the practical aspects of this kind of translation. This part consists of three chapters: 1 . The general characterization of political language 2 . Translating and adapting political texts. 3. The problematic nature of translating political speeches.

\subsection{The general characterization of political language}

Political and diplomatic languages belong to the category of the special languages used in social sciences, and as such are closely linked to the history of political thought. Both - as technical languages - are in close contact with rhetoric, since these special languages can be considered the terminological core of many spoken genres.

The scope and intent of political language are different from that of diplomatic language. While the latter is mainly used as the protocol language of official events and ceremonies, the former is adequate for carrying the utterances of historical genres as well (depicting historical events, personages and socially significant phenomena in the history of society, and presenting past representations of recent events whose social significance is recognized by contemporaries). As such, political language is suitable for recording data and facts (e.g. highlighting important legal and territorial changes and political events in the world, wars, treaties, etc.). 
The terminology of political language is related to the special language of political philosophy, since this terminology aids the formulation of the most common questions regarding the relationship between the individual and society. However, it is also related to political theory since political terminology is used to formulate the descriptive theories of political phenomena, too (such as social criticism, the principles of justice, law, etc.). It would not have been possible to elaborate state theories without political language, and concepts such as "good government" or "right form of government" could not have been created. The description of political ideas (doctrines, ideologies, and political programs and policy objectives) is also an important domain for the manifestation of political language. According to the foregoing ideas, political terminology can be considered a secondary discourse arising from the primary discourse, that is, a new discourse in which the primary discourse is alloyed with terminology (Sárosi 2011). Strongly related to the language of politics, the language of diplomacy is also an interesting segment of communication among different states. This is actually the language of international relations, and its character is closely related to the function it performs in the international arena. Thus, diplomatic language is closely related to the nature of the most important diplomatic tasks.

The political representations of different countries generally require the use of two or more languages and therefore the languages used on the scene of diplomacy are in permanent contact thus establishing, out of necessity, a kind of lingua franca of diplomacy. These scenes of diplomacy are: bilateral relations, relations with third countries and international organizations, international forums and non-political events with international impact.

Regarding the political issues there is a continuous relationship between the diplomatic delegation and the competent authorities of the receiving state. The language of these relationships may also take specific forms since, in many cases, the members of the diplomatic delegation do not speak the language of the host country at an appropriate level. In such cases a third language is involved in communication, or an interpreter is used, the latter representing a special form of diplomatic communication. Meetings between the senior leadership or a political delegation of the visiting country and that of the host country - as well as international diplomatic conferences and all the other similar events require special diplomatic language use, as do the preparation of international agreements, negotiation and the conclusion of treaties. The specialized language of politics and thus of diplomacy in many respects depends on the international actions, habits and the bilaterally agreed solutions. 


\subsubsection{The political texts as specific expressions of the political language}

If we want to specify the nature of the terminology of political language, it is useful to examine what constitutes the core of political texts. The scope of a political text can be: persuasion, reasoning, deceit or even hustling, all of which require a specific language use. The purpose of a persuasive speech is to convince the audience to agree with an idea or opinion that the speaker puts forth. One can produce an effective persuasive speech if he/she structures the arguments as the solution to a problem. The first job of the speaker or writer is to convince the audience that a particular problem is important to them, and then they must be convinced by the text that the speaker or writer has the solution for addressing the problem. Persuasive speeches can come in many forms, such as sales pitches, debates and political proceedings. Persuasive speeches may utilize emotional and/or logical appeals. Factors such as body language, the willingness of the audience, and the environment in which the speech is given, all affect the success of a persuasive speech.

Persuasive texts, whether written or spoken, can be considered a process aimed at changing a person's (or a group's) attitude or behavior. This is a long process. After a person is convinced regarding an issue, it is very difficult to change his/ her opinion. This requires a lot of energy. Lacking this energy, persuasion will fail and instead of persuasion we will only talk about adaptation to the expectations, or possibly about superficial acceptance of the argument, that can be considered the initial phase of persuasion (Cialdini 2001).

Successful persuasion requires the art of argumentation. A political argument is an instance of logical argument applied to politics. Political arguments are used by academics, media, candidates for political office and government officials. They may also be used by citizens in everyday interactions to comment on and understand political events. Political arguments are very often circular, repeating the same facts as premises under perhaps slightly different guises. Argumentation should be distinguished from propaganda, in that propaganda has little or no structure or rationality. A specific type of argument is the argument based on probability, which relies on an observation, experience or finding that the majority deems acceptable and true. Probably the most important arguments are those that rely on evidence: facts, statistical data, research results, summary reports, or reference to prestige (Zemplén - Kutrovátz 2012).

If persuasion based on argument does not achieve success, then deceit, misguidance and hustling follow. This means that in order to achieve their aim, the speakers present false data, show bogus statistics and make promises that cannot be kept due to objective circumstances. Politics is saturated with speeches: citizens and politicians speak, journalists and political analysts give speeches and, last but not least, political scientists speak as well (Cacioppo and Petty 1986). Regarding political texts it can be stated that subsequent readings 
create new interpretations resulting in the same text gaining new meaning and significance, yet, the most important question remains: what is the texts' meaning? what are they saying to us? To effectively answer this question, one must have a thorough knowledge of political jargon.

The discourse of the political sciences appears as professional language. Nevertheless, political speech cannot be considered in isolation from different yet strongly connected political discourses. The problems related to the linguistic aspects of politics appear the moment when a preliminary idea is formulated about the role of language in politics, and when language becomes a relevant issue from the perspective of political scopes as well.

Political terminology has the following functions:

- expressive function, meaning that it expresses aims that are rooted in the real sphere of politics;

- objective function, meaning that it has an objective reason to influence people's thinking, feelings, and thus their actions;

- symbolic function, meaning that thoughts and feelings are expressed by political symbols.

According to the symbolic approach, if someone is talking about symbolic politics, then (s)he refers to an individual area of politics that is genuine and separate from real and actual political issues. In habitual language use, symbolic politics means a publicly displayed deception or surrogate action that is used to detract from actual political reality. In this sense symbolic politics is considered to be a surrogate for politics. Symbolic politics differs from substantial policy. As a policy of signs (terms and slogans, badges, banners and pictures, gestures, ritual acts, and political staging), symbolic politics evolves in a semantic field. Substantial policy, by contrast, consists of a revisable succession of political decisions (e.g., legislation, contracts, taxes, etc.). Symbolic politics and substantial policy can be related to each other. On the one hand, symbolic politics can have an impact on substantial policy, while substantial policy can be communicated, implemented, or averted by symbolic politics (Sarcinelli 1998). If we try to define political jargon from the perspective of language policy, we notice that this conception of language directs attention to the concept of fighting (Szabó 2003). Assumptions:

- politics is primarily a linguistic arena, largely because the political struggles take place in the public space defined by the mass media;

- the benefits that are obtainable in this struggle - for example, linking the positive concepts with one's own political group and the negative ones with the opponents - can be directly converted into political gains;

- the ground for further political battles will be the pre-formed political space in which the winners of the symbolic political struggle will be favoured.

When approached from the perspective of the rhetoric, the analysis of the structure, tropes, symbols and metaphors used in the political speeches will 
become essential. This is so because, presumably, in these political speeches the political objectives and means of the speaker are expressed - mainly for manipulative intent - and because the ultimate objective of political speech is of course a rhetorical one, i.e. manipulation.

The analysis of political speeches, from the perspective of communication theory, comes to a particular prominence parallel to the professionalization of politics. In political communication, we are broadly interested in the relationship between politics and citizens, and the communication modes that connect these groups to each other. This theory describes political language as a category of human behavior, that is equal with other political actions and that has becomedue to the development of communication technologies and mass media - perhaps the most important form of political action. The language use has an entirely instrumental nature, the language itself being both the instrument and object of the actions. The basic question is how other political actions can be reinforced through the effectiveness of communication. Later, the idea has become prevalent that all political actions are interesting as they play a role in communication. As a result, it is obvious that the analysis of political communication refers not only to linguistic tools or matters of content but to strategies used to attain a position of power.

Proponents of the discursive approach analyze the political language because through this they wish to understand how the political actors shape the world around them. Here, the focus is not on the man acting with the aim of linguistic tools, but on the linguistically mediated interpretations, reports. Politics is a discursive process. The process consists of actors in the political system who take up problems/issues which are dealt with in other subsystems such as economy, and frame it as a political problem. In doing so, a political debate is launched in which the political problem, or to be more precise, solutions for the political problem are discussed. Those who are concerned with politics treat reality in the same way they treat symbols. People generally treat real things in the same way as they treat the referring concepts that have already been interpreted or commented somehow (Szabó 2003).

\subsection{Translating and adapting political texts}

Scientists have considered that it is only a matter of discipline, attention and technique that allows one to navigate the labyrinth of words and reach perfect understanding. This can be true only if we consider political language as a system open for deductive analysis and concrete definitions and not a simple manifestation of natural language use (Szabó 2001: 1). The political system, just like the language, continually undergoes a process of change because it is a living entity, and that is why the state of both the language and the political system is instantaneous. This is the reason why none of them are amenable to descriptive 
methods. Political language cannot be regarded as a compact technical language, though it presents some features of the terminology. Political expressions do not have an intrinsic value, they can be defined only in relation to the discourse of which they are the elements. Herbert Lyonel Adolphus Hart in his work entitled Definition and Theory in Legal Sciences emphasizes the following:

[...] the efforts for the definition of such expressions as state power, electoral system or the system of checks and balances show us that these words do not have real bonds to the conceptual world, as common words do... There is nothing out there in the real world that would conceptually suit these political expressions, there is no equivalent term or word in the everyday language (2000).

Political words cannot be analyzed in isolation, in their analysis one must take into consideration the whole sentence and even the entire discourse. If we want to analyze them, we must do it in their context, we must arrange them in phrases. The primary function of these words is not to describe something but to set up a relationship; this fact gives rise to the difference between these words and the rest of the lexicon (Hart 2000: 104).

From the pragmatic point of view we may state that the politician breaks from the normal language used by common people and forces them into a specific language domain. The political relevance of a given term makes itself visible only in this specific language, which destroys the everyday use of human language. Political language and common language do not differ in the way foreign languages do. One may ask why political language differs from common language. The prime reason for this kind of difference is that the semantic value of the political words is richer than that of normal words. For instance, men are sentenced to death in the name of the law, properties change owners based on the words of a contract (Simpson 2000: 144). In the case of performative political expressions the most important thing is the effect of the sentences on the people. These effects arise through the manifestation of language. Political effects are considered concrete effects (Olivecrona 2000: 174).

Political language forces us to reconstruct, through interpretation, those thoughts which are settled in the political text. This reconstruction is a mental process through which we rebuild the text according to our knowledge in order to gain a better understanding.

\subsubsection{Political language and translation}

A feature of the political system is that it is composed of strongly related texts, so while creating a new text (e.g. translations) we must pay attention to its coherence with the rest of the political texts. This coherence is ensured by 
political terminology (party of a contract, death-penalty, etc.) and by some nonterminological elements such as: regarding, breaking a contract, furthermore, etc. The tradition of the political text also contributes to this coherence, for which reason non-jurists may find political text impossible to understand. This is because the juridical system is a logical one, the texts of which try to avoid complex and heavy descriptions beyond the understanding of the common person, and which would require further study and analysis in order to be understood. The specific scope of these texts may explain the use of long phrases which present a hard task for the translator to deal with. To understand and, furthermore, to translate these texts one must interpret them.

One may face a situation in which the source language text (act or contract, deed of foundation or statute, etc.) is overcomplicated and unclear. Although this idea is in contradiction to that referring to the logical character of political texts, it can be seen that in practice, translators often face such situations as a result of the incompetence or lack of knowledge of those who have written the texts. The translator will become an interpreter only when faced with problems related to the act of translation, not to the content of the paper. The problem is even more considerable if the lack of clarity is due to the differences between the two language systems. During the process of translation the translator must reject creativity and instead accept the traditional specialized language. Specialized language in this study means: the terminology of a domain which mirrors that slice of reality which is the research territory of a certain circle of specialists (Kurtán 2003: 50).

It is not a simple task for the translator to deal with special terminology because he or she may have other linguistic preferences, or might not accept the existing calque-forms ${ }^{1}$ of expression. A further cause of difficulty might be the fact that documentation sources are not available to them (Várnai 2006: 48). In the case of political translations it is important that the translator use the existing source language terminology, because this becomes in fact the code of political communication and the tool of coherent texts. If the translators face new concepts during the translation process, they must take into consideration several political, linguistic and cultural aspects in order to reach the perfect or at least the most acceptable equivalent.

In the process of political translations one may find comparative study a useful method. It can be used to make a comparative study of the two language systems. This is an intellectual process that will enrich the reference system of the translator through the study of a different reference system. Another purpose

1 A calque or loan translation (itself a calque of German Lehnübersetzung) is a phrase borrowed from another language and translated literally word-for-word. You often see them in specialized or internationalized fields such as quality assurance (aseguramiento de calidad, assurance qualité, asigurarea calității taken from English). 
of this kind of study is to make a comparison between the two political systems and to identify common features as well as different characteristics.

Let us analyze how comparative study can help in the comparison of linguistic and thematic knowledge, and how this method can build a bridge between two different cultures and worlds. The interpretation and re-texting of a discourse in the form of an equivalent discourse written in another language will be possible only if the translator analyses the linguistic signs according to the extra-linguistic aspects. To produce a translation the translator will need a minimal knowledge of both political systems. Using the methods of comparative political study is important not only to understand how the respective political systems work, but also to place the text correctly in the receptive culture. The comparison is a theoretical method which helps to understand the power and the limits of the political actions in the two different political systems, and it also points out the convergent and divergent aspects of the two political systems. During the process of comparative study the translator gains thematic knowledge that becomes active and useful only in the very moment of translation. Regarding political translations the most difficult issue is the translation of political realia. ${ }^{2}$

As a translation technique, adaptation can be defined as a technical and objective method. The best-known definition is that of Vinay and Darbelnet, who list adaptation as a separate translation procedure: "adaptation is a procedure which can be used whenever the context referred to in the original text does not exist in the culture of the target text, thereby necessitating some form of re-creation." This widely accepted definition views adaptation as a procedure employed to achieve an equivalence of situations wherever cultural mismatches are encountered (1958).

Eugene Nida has noted that "language is a part of culture, and in fact, it is the most complex set of habits that any culture exhibits. Language reflects the culture, provides access to the culture, and in many respects constitutes a model of the culture." (1964) In order to render culture specific elements and to reflect a certain model of culture, translators may use the following techniques:

- omission: the elimination or reduction of part of the text;

- expansion: making explicit information that is implicit in the original, either in the main body or in footnotes or a glossary;

- exoticism: the substitution of stretches of slang, dialect, nonsense words, etc. in the original text by rough equivalents in the target language (sometimes marked by italics or underlining);

- updating: the replacement of outdated or obscure information by modern equivalents;

2 Specific material elements that exist only in a certain political system / regime (based on analogy with the culture-specific items). 
- situational equivalence: the insertion of a more familiar context than the one used in the original;

- creation: a more global replacement of the original text with a text that preserves only the essential message/ideas/functions of the original.

\section{The problem of translating political speeches}

A political speech is a speech which relates to government matters as opposed to the affairs of an individual or organization. It gives an insight into the political views of the speaker and may either sway listeners in their favor or not.

This chapter of the paper will present the Hungarian and Romanian translations of Sir Winston Churchill's speech entitled "The Sinews of Peace". ${ }^{3}$ Churchill was out of office at the time of his famous speech in Fulton, Missouri, in 1946, after the Labour Party's landslide victories in the July 1945 election. He was invited to give the Green Lecture, named for the John Findley Green, an alumni of Westminster College and was introduced by President Harry Truman to deliver this address on 5 March 1946.

According to Robert Rhodes-James:

This speech may be regarded as the most important Churchill delivered as Leader of the Opposition (1945-1951). It contains certain phrases - "the special relationship," "the sinews of peace" - which at once entered into general use, and which have survived. But it is the passage on "the iron curtain" which attracted immediate international attention, and had incalculable impact upon public opinion in the United States and in Western Europe. Russian historians date the beginning of the Cold War from this speech. In its phraseology, in its intricate drawing together of several themes to an electrifying climax - this speech may be regarded as a technical classic. (Rhodes-James et al. 1969)

This speech is known for one of its most famous phrases, "Iron Curtain" but it's also known as the "Sinews of Peace" speech. (Churchill never named his own speeches.) The historical context of the speech is of particular relevance. In 1946, the year following the end of World War Two, there were major shortages in jobs and housing for those returning from war in Britain. Conditions were made worse by nature's vagaries. In 1946 a world-wide wheat shortage necessitated bread rationing, and the exceptionally severe winter of 1946-7 meant that even potatoes were rationed (both these basics had been freely available throughout the war).

3 The address, although known as the "iron curtain speech", had been given the title "the sinews of peace" speech by Churchill. It captured the moment between the optimism at the end of the war and the deepening awareness of the risk of future conflicts. 
The nation's finances, too, were in severe deficit, until much-needed help from the USA in the form of Marshall Aid. The international situation made a rapid return to peacetime conditions equally impossible, yet another war was knocking on the door of Europe: the Cold War that was to separate the old continent into capitalist and communist blocks for almost four decades.

The translation of such a text is certainly not an easy task. The translated versions of the speech are not spoken texts, yet their role is significant as only through the act of translation can it be understood by people all around the world. The speech was translated into many languages, among them Hungarian and Romanian. In the following part of the paper we will analyze some excerpts from the famous speech and their Hungarian and Romanian translations.

In the corpus, besides the original text, we included the Hungarian version elaborated by László Horváth and the Romanian version elaborated by Luca Octavian. The Hungarian translation is included in the book entitled Sohase engedjetek! : Winston Churchill legjobb beszédei (Never give in!), published in 2006 by Európa Publishing House (Hungary). The translation used in this book was elaborated in 1950. The Romanian text is in fact a subtitle attached to the speech accessible on Youtube. Thus the year of its elaboration cannot be stated precisely.

\begin{tabular}{|c|c|c|}
\hline $\begin{array}{l}\text { A shadow has fallen } \\
\text { upon the scenes so lately } \\
\text { lighted by the Allied } \\
\text { victory. }\end{array}$ & $\begin{array}{l}\text { Árnyék borult arra a } \\
\text { színpadra, amelyet } \\
\text { legutóbb a szövetségesek } \\
\text { győzelme megvilágított. }\end{array}$ & $\begin{array}{l}\text { S-a lăsat o umbră peste } \\
\text { scenele atât de luminate, } \\
\text { până nu demult, de } \\
\text { victoriile Aliaților. }\end{array}$ \\
\hline
\end{tabular}

(Excerpt 1)

In the excerpt above the most interesting element to translate is the metaphor shadow, which is meant to express the difficulties of the era following the war. Both the Hungarian and the Romanian translator succeeded in finding the adequate equivalent of the noun shadow, yet the feeling of the translated texts is different if compared to the source text. The original version is short and precise expressing the shock that the victorious nations had to suffer after the euphoria of the victory was over. The impact of this short and concise sentence is so strong that the audience may almost feel the shudder caused by the dark shadow. The Hungarian and the Romanian translations follow the spirit of the original, although they seem much more artificial yet they are faithful to the source text. We can say that something is lost in translation, in spite of the fact that transfer operations were successfully applied and a quite appropriate translation was elaborated. 


\begin{tabular}{|c|c|c|}
\hline $\begin{array}{l}\text { Nobody knows what } \\
\text { Soviet Russia and its } \\
\text { Communist international } \\
\text { organisation intends } \\
\text { to do in the immediate } \\
\text { future, or what are } \\
\text { the limits, if any, to } \\
\text { their expansive and } \\
\text { proselytising tendencies. }\end{array}$ & $\begin{array}{l}\text { Senki sem tudja, mit } \\
\text { szándékozik tenni } \\
\text { Szovjet-Oroszország és } \\
\text { nemzetközi kommunista } \\
\text { szervezete a közvetlen } \\
\text { jövőben, sem azt hol } \\
\text { vannak a korlátai, ha } \\
\text { vannak egyáltalán } \\
\text { korlátai expanziós } \\
\text { és követőket toborzó } \\
\text { irányzatainak. }\end{array}$ & $\begin{array}{l}\text { Nimeni nu ştie ce } \\
\text { intenționează să facă, } \\
\text { în viitorul apropiat, } \\
\text { Rusia sovietică şi } \\
\text { organizația sa comunistă } \\
\text { internațională sau care } \\
\text { sunt limitele, dacă ele } \\
\text { există, ale tendințelor } \\
\text { sale expansioniste şi de } \\
\text { prozelitism. }\end{array}$ \\
\hline
\end{tabular}

(Excerpt 2)

Excerpt 2 is a very interesting one from the point of view of equivalence. The Hungarian and the Romanian translations are almost perfect imprints of the original text conserving both the form and the message, the translator performing only the compulsory transfer operations without using any other kind of translation strategy or method of compensation. Thus we may characterize these translations by equivalence as named by Nida formal equivalence.

Nida (1964) argued that there are two different types of equivalence, namely formal equivalence, which in the second edition by Nida is referred to as formal correspondence, and dynamic equivalence. Formal correspondence focuses attention on the message itself, in both form and content, unlike dynamic equivalence, which is based upon the principle of equivalent effect. Formal correspondence consists of a target language item which represents the closest equivalent of a source language word or phrase (communist international organisation - nemzetközi kommunista szervezete - organizația sa comunistă internațională, intends to do - mit szándékozik tenni - ce intenționează să facă, in the immediate future - a közvetlen jövóben - în viitorul apropiat). Nida makes it clear that there are not always formal equivalents between language pairs (Nida, 1964), he therefore suggests that these formal equivalents should be used wherever possible if the translation aims at achieving formal rather than dynamic equivalence. The use of formal equivalents might at times have serious implications in the target texts since the translation in some cases might not be easily understood by the target audience. The opposite of formal equivalence is called dynamic equivalence, defined as a translation principle according to which a translator seeks to translate the meaning of the original in such a way that the target language wording will produce the same impact on the target-text's audience as the original wording did upon the source-text's audience (Nida 1964). The excerpt above is a good example of how these two types of equivalence can be perfectly intermingled. The phrases listed above are translated word-for-word, yet this does not influence the perfect rendering of the meaning and spirit of the text. 


\begin{tabular}{|c|c|c|}
\hline $\begin{array}{l}\text { From Stettin in the } \\
\text { Baltic to Trieste in the } \\
\text { Adriatic, an iron curtain } \\
\text { has descended across the } \\
\text { Continent. }\end{array}$ & $\begin{array}{l}\text { A Balti-tenger mellett } \\
\text { fekvő Stettintól az } \\
\text { Adriai-tenger mentén } \\
\text { fekvő Triesztig } \\
\text { vasfüggöny ereszkedik le } \\
\text { Európára. }\end{array}$ & $\begin{array}{l}\text { De la Stettin, în Baltica, } \\
\text { la Trieste, în Adriatica, } \\
\text { o cortină de fier s-a lăsat } \\
\text { peste Continent. }\end{array}$ \\
\hline
\end{tabular}

(Excerpt 3)

In Excerpt 3 another very expressive metaphor appears, which is perhaps the most important one of the speech. The term becomes the metaphor for the borderline that separates Europe and even the entire world into two totally different parts: the West with the USA as its protector and the East with the Soviet Union as its "father" and ruler. Thus the task of the translator is even more difficult as he/she must find a perfect equivalent, an adequate term which will enter the history books and even history as well. The equivalence achieved is textual since the correspondence between the source language text and the target language texts in terms of information and cohesion is created, the key metaphor is transferred in and adequate manner.

\begin{tabular}{|c|c|c|}
\hline $\begin{array}{l}\text { Whatever conclusions } \\
\text { may be drawn from } \\
\text { these facts - and } \\
\text { facts they are - this } \\
\text { is certainly not the } \\
\text { Liberated Europe we } \\
\text { fought to build up. }\end{array}$ & $\begin{array}{l}\text { Bármilyen } \\
\text { következtetéseket } \\
\text { vonjunk le ezekból a } \\
\text { tényekboól - mert ezek } \\
\text { tények -, bizonyára } \\
\text { nem az a felszabadított } \\
\text { Európa ez, amelynek a } \\
\text { felépítéséért harcoltunk. }\end{array}$ & $\begin{array}{l}\text { Oricare ar fi concluziile ce } \\
\text { pot fi trase din aceste fapte } \\
\text { - şi faptele există -, aceasta } \\
\text { cu siguranță nu este Euro- } \\
\text { pa Eliberată pe care noi am } \\
\text { luptat s-o realizăm şi nici } \\
\text { nu este una care să conțină } \\
\text { elementele esențiale ale păcii } \\
\text { permanente. }\end{array}$ \\
\hline
\end{tabular}

(Excerpt 4)

Excerpt 4 poses a new set of problems that relate to the issue of translatability vs. untranslatability. In the case of this excerpt sociosemiotic untranslatability, more precisely, referential untranslatability appears. Referential untranslatability occurs when a referential element in the source message is not known or readily comparable to a particular item in the target language. The phrase Liberated Europe is a new referential element that appears in English language political discourse, thus, translating it is a very tender ground for any translator. In the Hungarian translation the attribute felszabaditott is not capitalized, while in the Romanian translation - as in the original - it is. This aspect is important only if the speech is transposed in writing, since as an oral genre it is not relevant whether a lexeme is capitalized or not. In oral genres the intonation is more important as it is used 
for indicating the attitudes and emotions of the speaker, focusing attention on important elements of the spoken message. Yet, the difference shown above is not negligible as it suggests the importance of the phrase.

\begin{tabular}{|c|c|c|}
\hline $\begin{array}{l}\text { The safety of the world } \\
\text { requires a new unity } \\
\text { in Europe, from which } \\
\text { no nation should be } \\
\text { permanently outcast. It } \\
\text { is from the quarrels of } \\
\text { the strong parent races } \\
\text { in Europe that the world } \\
\text { wars we have witnessed, } \\
\text { or which occurred in } \\
\text { former times, have } \\
\text { sprung. }\end{array}$ & $\begin{array}{l}\text { A világ biztonsága újfajta } \\
\text { egységet igényel Európá- } \\
\text { ban, olyat, amelyikből egy } \\
\text { nemzetet sem lehet tartó- } \\
\text { san kirekeszteni: Európa } \\
\text { nagy alapító nemzeteinek } \\
\text { ellenségeskedései robban- } \\
\text { tották ki azokat a világhá- } \\
\text { borúkat, melyeknek tanúi } \\
\text { voltunk, vagy amelyek } \\
\text { korábban zajlottak. }\end{array}$ & $\begin{array}{l}\text { Securitatea mondială } \\
\text { presupune o nouă unitate } \\
\text { în Europa, de la care nici } \\
\text { o națiune nu trebuie de- } \\
\text { finitiv exclusă. Animozi- } \\
\text { tăților dintre puternicile } \\
\text { rase originare ale Europei } \\
\text { li s-a datorat izbucnirea } \\
\text { celor două războaie mon- } \\
\text { diale la care am fost mar- } \\
\text { tori, s-au care s-au desfă- } \\
\text { şurat în ultima perioadă. }\end{array}$ \\
\hline
\end{tabular}

(Excerpt 5)

Excerpt 5 is difficult to translate due to the phrase strong parent races in Europe. This phrase is translated into Hungarian with the phrase Európa nagy alapító nemzetei and into Romanian with the phrase puternicile rase originare ale Europei. The English phrase is more expressive and a lot deeper in feeling, as it appeals to the patriotism of all European nations. The Hungarian translation simply refers to the fact that there are more important and less important nations in Europe that influence the course of history. The Romanian translation is closer to the Hungarian translation in spirit than to the source language text. This suggests that both translators - without having anything in common and probably creating their translations in different milieus and eras - operated by the means of up-down text construction that made it possible to elaborate a freer and more original-like text. Regarding the excerpt we can conclude that on the textual level the translations follow the original and if necessary they explain and interpret.

\begin{tabular}{lll}
\hline Surely we should & Tudatosan kellene & Cu certitudine, noi \\
work with conscious & dolgoznunk azért, hogy & trebuie să lucrăm pentru \\
purpose for a grand & az Egyesült Nemzetek & a conştientiza necesitatea \\
pacification of Europe, & Szervezetén belül & unei mari pacificări \\
within the structure of & annak alapokmányával & a Europei, în cadrul \\
the United Nations and & összhangban, egész & structurii Națiunilor \\
in accordance with its & Európára kiterjedően & Unite şi în conformitate \\
Charter. & megvalósíthassuk a békét. & cu Carta sa. \\
\hline
\end{tabular}


The Romanian translation of Excerpt 6 is almost a word-for-word translation of the source language text. Thus, regarding equivalence we may speak about rank bound translation (Catford 1965). This term is introduced by Catford, who proposed very broad types of equivalence in translation according to three criteria: (a) The extent of translation (full translation vs. partial translation), (b) The grammatical rank at which the translation equivalence is established (rank-bound translation vs. unbounded translation), (c) The levels of language involved in translation (total translation vs. restricted translation). Rank-bound translation takes place when equivalence is sought at levels lower than the sentence but shifts that occur at this level result in bad translations as the target language text will not be an easy read. This is what happened in the case of the Romanian translation of the above excerpt.

\begin{tabular}{lll}
\hline In front of the iron & Az Európát átszeló & Alături de Cortina de \\
curtain which lies across & vasfüggönyön kívül & Fier care se află peste \\
$\begin{array}{l}\text { Europe are other causes } \\
\text { for anxiety. }\end{array}$ & más okunk is van a & Europa, există şi alte \\
nyugtalanságra. & cauze de nelinişte. \\
\hline
\end{tabular}

(Excerpt 7)

In Excerpt 7 the most important translation-related issue is the translation of the adverbial phrase in front of the, that is translated into Hungarian by a postposition expressed by a present participle (átszeló), while into Romanian by a prepositional phrase (alături de). The exact meaning of the Hungarian equivalent used in the translation is crossing, and the exact meaning of the Romanian term is next to or near. None of these express exactly the meaning of the English phrase, yet they can be considered adequate as both of them express the viewpoint and attitude of their translators towards the concept of the iron curtain that separates Europe.

\begin{tabular}{lll}
\hline $\begin{array}{l}\text { Nevertheless the future } \\
\text { of Italy hangs in the } \\
\text { balance. }\end{array}$ & $\begin{array}{l}\text { Olaszország jövője } \\
\text { egyébként sem dôlt még } \\
\text { el. }\end{array}$ & $\begin{array}{l}\text { Cu toate acestea, viitorul } \\
\text { Italiei se află pe muchie } \\
\text { de cuțit. }\end{array}$ \\
\hline
\end{tabular}

(Excerpt 8)

In Excerpt 8 the most interesting translation-related item is the translation of the verb hangs that is translated in Hungarian by a negative phrase sem dólt még el. This transfer operation is called modulation in literature, defined by Gérard Hardin and Gynthia Picot (1990) as a change in point of view that allows us to express the same phenomenon in a different way. The Romanian translation of the same verb is even more interesting as it uses an idiomatic expression se află pe muchie de cuțit. This kind of translation has a compensating effect, as a nonfigurative expression is expressed in the target language with an idiom. Both 
the Hungarian and the Romanian translations become richer in meaning than the original text. The Hungarian text suggests that a historical problem needs to be solved in the future and the Romanian text expresses that the situation is very serious and has a great importance for the future of the entire Europe.

\begin{tabular}{lll}
\hline All my public life I have & Amióta csak kiléptem & Toată viața mea publică \\
worked for a strong & a nyilvánosság & am actionat pentru \\
France and I never lost & elé, Franciaország & o Franță puternică şi \\
faith in her destiny, even & megerősödéséért & niciodată nu mi-am \\
in the darkest hours. & tevékenykedtem, és & pierdut credința în \\
& még a legsötétebb & destinul ei, chiar şi în \\
& pillanatokban sem & cele mai grele momente. \\
& veszítettem el iránta & \\
& érzett bizalmamat. & \\
\hline
\end{tabular}

(Excerpt 9)

Reading the Romanian translation of Excerpt 9 we can see that the phrase viața mea publică is a literal and non-adequate translation of the phrase my public life used by the speaker in the original text. The translator should have used another translation procedure like explicitation or adaptation, just as the Hungarian translator did. The phrase kiléptem a nyilvánosság elé is a more expressive option and it better renders the feelings and the purpose of the speaker. In the Romanian translation an addition should have been used to make it explicit that the speaker, as a very important political and historical personality wants to emphasize his beliefs and his faith in the future. For a more appropriate correspondence a phrase like toată viața mea pe scena politică or toată viața mea ca şi personaj politic should have been used in the Romanian translation, too. In this case appropriate translation means the adequate transposition of the source text in the target language respecting the basic rules of target-orientedness.

\begin{tabular}{lll}
\hline I will not lose faith now. & $\begin{array}{l}\text { Most sem fogom } \\
\text { elveszíteni. }\end{array}$ & $\begin{array}{l}\text { Nu îmi voi pierde această } \\
\text { credință acum. }\end{array}$ \\
\hline
\end{tabular}

(Excerpt 10)

The translation of the sentence included in Excerpt 10 is once again a literal translation, yet in the Hungarian text we may observe an omission. The translator omitted the noun faith, without having any impact on the meaning of the text, as it is obvious from the context what the speaker refers to. The Romanian translation is complete, there is no omission and even the word order is preserved. Thus we may conclude that these two translations mirror the source text both syntactically and semantically. 


\section{Conclusions}

The translation of political speeches can be studied from a linguistic perspective, but it can also be looked at from a broader perspective, based on the theory of the political discourse and on research related to the study of special languages.

The prominent feature of the style of political speeches is very long sentences. This predilection for lengthy sentences is due to the need to place all information on a particular topic in one complete unit, in order to reduce the ambiguity that may arise if they are put in different sentences (e.g. There is deep sympathy and goodwill in Britain - and I doubt not here also - towards the peoples of all the Russia and a resolve to persevere through many differences and rebuffs in establishing lasting friendships.). A political speech is always phrased in a very personal manner so as to address the chosen target audience (In this country you are all so well-informed about the Far East, and such devoted friends of China, that I do not need to expatiate on the situation there. On the other hand I repulse the idea that a new war is inevitable; still more that it is imminent.)

Another feature is the flexible or vague language. Politicians try to be as imprecise as possible and use general, vague and hazy language. Metaphoric and abstract language is typical of political speeches that are ideally written to have great impact on the actual audience (What they desire is the fruits of war and the indefinite expansion of their power and doctrines.).

Due to these features political speeches are hard to translate and they can sometimes be included in the category of untranslatable text. Politicians do not deliver their speeches to be translated for foreign audiences. Thus in some cases translators cannot produce parallel texts that are identical in meaning, or in their political and historical effect. Thus the translator's main task is to create a text that will transmit the core of the message included in the original text. To do so, the translator must be able "to understand not only what the words mean and what a sentence means, but also what political or historical impact could it have. They also have to know how to achieve that certain effect in the other language." (Quentel 2006: 3) Translators must be able to use language effectively to express the most important political concepts in order to achieve the desired effect. They must be familiar with the conventional rules and styles of political speeches (rhetoric, stylistics).

Yet, there are many strategies for translating the untranslatable, like explicitation or using footnotes, but in all of these cases there is loss of the original meaning, which can be compensated for in other parts of the text or discourse. According to Gadamer "no translation can replace the original [...] the translator's task is never to copy what is said, but to place himself in the direction of what is said (i.e. in its meaning) in order to carry over what is to be said into the direction of his own saying" (quoted by Newmark 1988: 79). 


\section{References}

Cacioppo, J. T. and R. E. Petty. 1986. The Elaboration Likelihood Model of Persuasion. Advances in Experimental Social Psychology 19 (1): 123-205.

Catford, J. C. 1965. A Linguistic Theory of Translation: an Essay on Applied Linguistics. London: Oxford University Press.

Cialdini, R. B. 2001. Influence: Science and Practice. Boston: Allyn \& Bacon.

Hardin, G. and Picot, C. 1990. Translate: Initiation à la pratique de la traduction

[To translate: An Introduction in the Practice of Translation]. Paris: Aubin Imprimeur.

Hart, H. L. 2000. Meghatározás és elmélet a jogtudományban. [Definition and Theory in the Science of Law]. In Szabó M., Varga Cs. (eds.), Jog és nyelv [Law and Language], 98-132. Budapest: PPKE.

Jakobson, R. 1966. On Linguistic Aspects of Translation. In R.A. Brower (ed.), On Translation, 107-239. New York: Oxford University Press.

Klaudy, K. 2003. Languages in Translation: Lectures on the Theory, Teaching and Practice of Translation. Budapest: Scholastica.

Kurtán Zs. 2003. Szakmai nyelvhasználat [Language for Special Purposes]. Budapest: Nemzeti Tankönyvkiadó.

Lederer, M. 2003. The Interpretive Model. Manchester: St. Jerome.

Newmark, P. 1988. A Textbook of Translation. Hertfordshire: Prentice Hall.

Nida, E. 1964. Toward a Science of Translation - with Special Reference to Principles and Procedures Involved in Bible Translating. Leiden: Brill.

Olivecrona, K. 2000. A jogi nyelv és a valóság [Legal Language and Reality]. In Szabó M. and Varga Cs (eds.), Jog és nyelv [Law and Language], 153-216. Budapest: PPKE.

Quentel G. 2006. Translating a Crucial Political Speech.

http://www2.warwick.ac.uk/fac/soc/csgr/research/workingpapers/2006/ wp20406.pdf (accessed 14 May, 2014)

Reiss, K. 1995. Text Type Translation and Translation Assessment. In Chesterman, A. (ed.), Reading in Translation Theory, 58-96. Helsinki: FinnLectura.

Rhodes-James R., Taylor, A. J. P, Plumb, J. H. et al. 1969. Churchill: Four Faces and the Man. London: The Penguin Press.

Sarcinelli, U. 1998. Politikvermittlung und Demokratie in der Mediengesellschaft [Politics and Democracy Seen through the Media]. Bonn: BpB.

Sárosi, K. 2011. Limbajul juridic şi traducerea [Legal Language and Translation]. In Butiurcă D., Druță, I. and Imre, A. (eds.), Terminology and Translation Studies, 211-227. Cluj Napoca: Scientia Publishing House.

Simpson, A.W.B. 2000. A jogi fogalmak elemzése [Defining Legal Concepts]. In Szabó M. and Varga Cs. (eds.), Jog és nyelv [Law and Language], 133-153. Budapest: PPKE. 
Szabó, Márton. 2003. A diszkurzív politikatudomány alapjai [The Bases of Discursive Politics]. Budapest: L'Harmattan Kiadó.

Szabó, Miklós. 2000. Szó szerint: a jog és a nyelv interferenciájáról [Word by Word: On the Interferences of Language and Law]. In Szabó M. and Varga Cs. (eds.), Jog és nyelv [Law and Language], 1-98. Budapest: PPKE.

Szabó, Miklós. 2001. Játsszunk! [Let’s play!]. In Szabó, Miklós (ed.), Ius humanum. Ember alkotta jog. Mühelytanulmányok [Ius Humanum. Law Made by Man. Studies], 41-73. Miskolc: Bíbor.

Várnai Sz. 2006. Jogi szövegek, szerződések és jogszabályok fordításának sajátosságai [Peculiarities of Translating Juridical Texts, Contracts and Laws]. In Környei Tibor (ed.), Fordítástechnikai útmutató [A Practical Guide for Translators], 46-53. Budapest: MFE.

Vinay, J. P., Darbelnet, J. 1958. Stilistique acomparée du français et de l'anglais. Methode de traduction [Comparative Stylistics of French and English: A Methodology for Translators]. Paris: Didier.

Zemplén, G. and Kutrovátz, G. 2012. Érvelés-tanulmányok [Essays on Argumentation]. BME FiTuTö, https://www.filozofia.bme.hu/sites/default/ files/anyagok/1295/rvel\%C3\%A9selm\%C3\% A9let-filmeken_02.pdf (accessed on 14 Feb., 2014) 